\title{
Pencahayaan dalam Ruang Tertutup menggunakan Solar Illumination
}

\author{
Suyatno, ${ }^{*}$ Gatut Yudoyono, dan Isa Albanna \\ Jurusan Fisika-FMIPA, Institut Teknologi Sepuluh Nopember \\ Kampus ITS Sukolilo, Surabaya 61111
}

\begin{abstract}
Intisari
Telah dilakukan penelitian tentang perancangan pencahayaan alami dalam ruang tertutup dengan menggunakan solar illumination. Dalam solar illumination terdapat dua sistem, yaitu sistem optika geometri untuk pemanduan cahaya dan sistem solar tracker untuk optimalisasi pelacakan arah sumber cahaya. Mekanisme pemanduan cahaya adalah dengan mengumpulkan cahaya menjadi berkas titik oleh panel solar concentrator yang kemudian dipandu menggunakan fiber optik untuk didistribusikan ke ruangan. Berdasarkan hasil penelitian, diperoleh data bahwa efisiensi sistem solar illumination adalah $12,00 \%$, sehingga dapat memberikan wacana tentang pemanfaatan energi matahari tidak terbatas hanya pada tinjauan termal dan listrik (solar cell). Energi matahari dapat dimanfaatkan dalam bidang pencahayaan yang sehat dan hemat energi pada ruang tertutup.
\end{abstract}

KATA KUNCI: cahaya, efisiensi, energi, solar illumination, solar tracker

\section{PENDAHULUAN}

Ketersediaan energi di indonesia belum mampu mencukupi tingkat konsusmsi oleh masyarakat yang relatif besar, sehingga perlu dilakukan pencarian sumber energi baru dan melakukan efisiensi energi [1]. Salah satu langkah efisiensi energi adalah pengunaan genteng kaca untuk pencahayaan saat siang hari. Genteng kaca memiliki kekuranga, yaitu cahaya yang masuk pada genteng kaca tidak dapat dipandu hingga ke ruang yang jauh. Untuk menyempurnakan teknologi genteng kaca, muncul adanya gagasan tentang perancangan pencahayaan alami dengan sumber cahaya matahari. Gagasan ini merupakan wujud pengembangan dibidang fisika bangunan untuk penghematan energi dalam gedung.

Pemanfaatan energi matahari untuk pencahayaan merupakan langkah yang tepat untuk menciptakan pencahayaan ruang yang sehat dan hemat energi. Matahari memancarkan beberapa spektrum radiasi, diantaranya adalah spektrum cahaya tampak ( $\lambda=380-770 \mathrm{~nm})$, spektrum Far Infra Red (FIR), dan beberapa spektrum lainya [2].

Pencahayaan alami merupakan kebutuhan yang penting dalam sebuah bangunan. Pencahayaan alami mampu memberikan efisiensi energi dalam gedung. Pengembangan bentuk arsitektur pencahayaan alami sudah dikembangkan sejak zaman manusia primitif, hingga berkembang sampai sekarang. Hasil riset yang memadukan estetika arsitektur, efisiensi energi, dan pencahayaan (iluminasi) melahirkan beberapa inovasi baru, diantaranya adalah solar tube, jendela, dan piped sunlight [3].

Pada artikel ini dilaporkan hasil perancangan sistem pencahayaan alami terangkai dalam solar illumination. Bentuk perancangan solar illumination yang didalamnya meng-

\footnotetext{
*E-MAIL: kangyatno@physics.its.ac.id
}

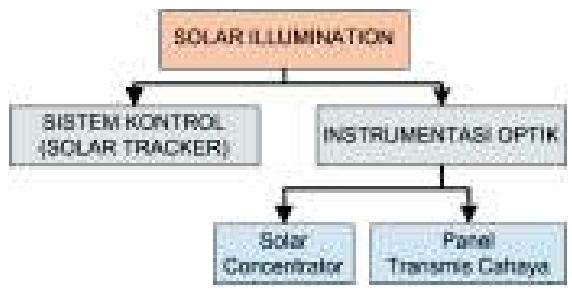

Gambar 1: Diagram Perancangan solar illumination

implementasikan dua sistem, yaitu sistem solar tracker dan sistem instrumentasi optik (solar concentrator dan panel transmisi cahaya). Penggunaan pencahayaan alami mengunakan solar illumination tercipta sistem pencahayaan yang sehat dan hemat energi pada ruang tertutup.

\section{METODOLOGI PERANCANGAN}

Secara umum bentuk alur metodologi perancangan yang dilakukan dalam penelitian ini adalah seperti pada Gambar 1, yaitu gambar bagan skematik kerja.

Perancangan yang telah dilakukan dalam penelitian ini adalah perancangan sistem solar ilumination. Sistem ini terdiri dari elektronika (solar tracker) dan sistem instrumentasi optik (solar concentrator dan panel transmisi). Solar tracker yang telah dirancang memiliki kemampuan untuk mengikuti arah berkas sumber cahaya agar cahaya yang mengenai solar concentrator dapat optimum. Pada Gambar 2(a) merupakan morfologi solar tracker yang telah dirancang dalam penelitian ini. Sensor yang digunakan untuk proses kontrol dalam solar tracker adalah sensor LDR. Pemasangan sensor LDR seperti pada Gambar 2(b). Proses kontrol gerakan dalam proses tracking dibantu dengan mikrokontrol AVR.

Sistem instrumentasi optik yang telah dirancang terdiri dari 


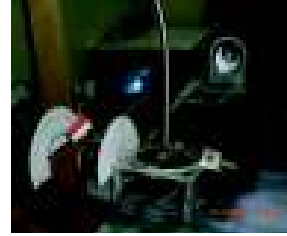

(a)

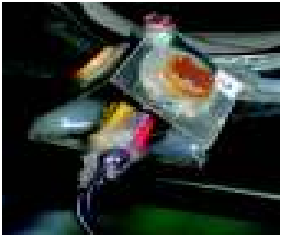

(b)

Gambar 2: a) Solar Tracker, b) Peletakan sensor LDR

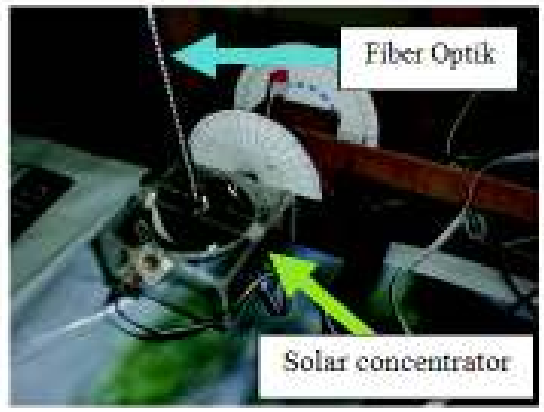

Gambar 3: Panel solar concentrator dan transmisi fiber optik

bentuk panel solar concentrator dan panel transmisi cahaya berupa fiber optik (jenis bundle). Panel solar concentrator merupakan panel berbentuk cermin cekung dengan fokus tertentu. Pada Gambar 3 merupakan bentuk panel solar concentrator dan panel transmisi fiber optik.

\section{HASIL DAN PEMBAHASAN}

Pada penelitian ini pembahasan difokuskan dalam beberapa point utama, yaitu seperti pada Gambar 4.

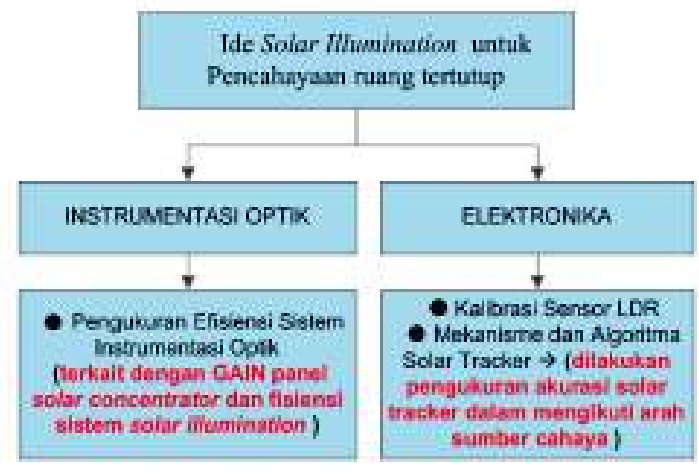

Gambar 4: Point fokus bahasan

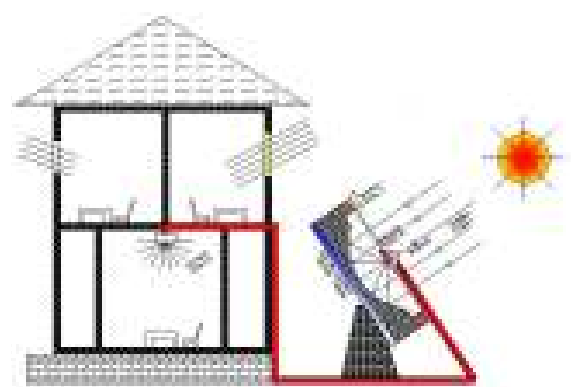

Gambar 5: Ilustrasi berkas cahaya pada solar illumination.

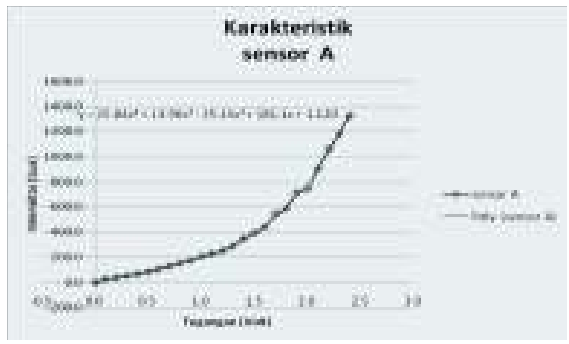

Gambar 6: Grafik hasil kalibrasi sensor LDR.

\section{A. Solar Illumination untuk Pencahayan Ruang Tertutup}

Solar illumination merupakan sistem yang digunakan untuk pencahayaan ruang tertutup. Tinjauan ruang tertutup dalam artikel ini adalah ruang yang tidak dimungkinkan cahaya matahari bisa masuk secara langsung. Prinsip kerja secara umum dari solar illumination ini adalah berkas cahaya dari luar dikumpulkan dan ditransmisikan mengunakan media tertentu dengan teknik pemanduan cahaya hingga sampai ruang yang diinginkan.

Kegunaan solar tracker adalah untuk mengatur keterarahan sudut panel solar concentrator dan menjaga agar panel tersebut tetap menghadap tegak lurus dengan sumber cahaya. Berkas cahaya sejajar yang mengenai solar concentrator akan dikumpulkan pada titik fokus. Hasil pemfokusan cahaya tersebut nantinya akan ditransmisikan mengunakan fiber optik hingga ke dalam ruangan.

\section{B. Kalibrasi Sensor LDR}

Solar tracker dikontrol mengunakan sensor cahaya (LDR). Sebelum digunakan untuk membaca kuat penerangan, LDR perlu dikalibrasi terlebih dahulu dengan mengunakan lux meter standart (LX-1108). Hal tersebut dilakukan karena sifat pada setiap LDR tidak sama. Proses kalibrasi yang dilakukan adalah dengan mencari fungsi alih untuk mengubah dari tegangan ke dalam satuan lux. Pada Gambar 6, merupakan fungsi alih yang didapat dari hasil kalibrasi.

Dari Gambar 6 terlihat bahwa hasil karakterisasi sensor LDR menggunakan luxmeter LX-1108 menunjukkan per- 


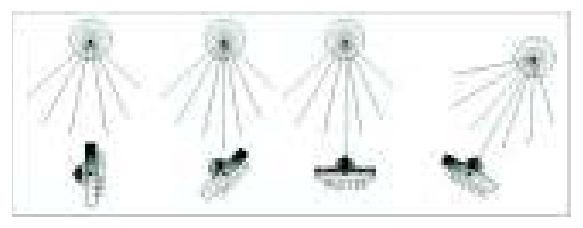

Gambar 7: Gerakan solar tracker

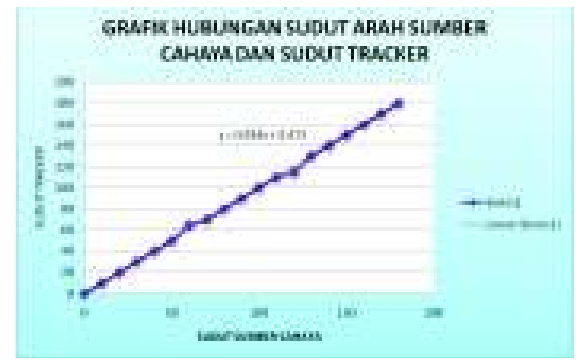

Gambar 8: Grafik akurasi solar tracker

samaan polinomial orde empat :

$$
y=25,84 x^{4}+13,96 x^{3}-25,15 x^{2}+181,1 x+1.120
$$

dengan $\mathrm{y}=$ iluminasi, $\mathrm{x}=$ keluaran nilai tegangan.

\section{Mekanisme dan Algoritma Solar Tracking}

Solar tracker merupakan bentuk spesifikasi dari jenis robot penjejak (tracker robot) yaitu robot yang mampu melacak atau mengikuti lintasan. Bentuk spesifikasi robot tracker yang digunakan untuk mengikuti gerakan matahari disebut solar tracker. Proses kontrol dari solar tracker mengunakan sensor LDR, mikrokontrol, dan aktuator berupa motor stepper. Dalam alogritma solar tracker, nilai hasil pengindraan sensor LDR dipakai sebagai referensi arah gerakan motor untuk mengikuti intensitas cahaya yang paling terang seperti pada Gambar 7.

Hasil pengujian solar tracker dapat digambarkan pada Gambar 8. Pada grafik tersebut terlihat solar tracker yang dirancang masih memiliki error.

\section{Efisiensi Sistem Instrumentasi Optik}

Sistem instrumentasi optik dalam solar illumination merupakan sistem yang memegang peran penting dalam pentransmisian cahaya. Pada sistem tersebut terdiri dari solar concentrator dan fiber optik sebagai media transmisi cahaya. Perhitungan efisiensi sistem instrumentasi optik dalam solar illumination dapat dilakukan dengan cara sebagai berikut :

- Mengukur gain pada solar concentrator.

- Mengukur efisiensi transmisi cahaya pada solar illumination.
TABEL I: Gain Solar Concentrator

\begin{tabular}{cccc}
\hline \multirow{2}{*}{$\begin{array}{c}\text { Pengukuran } \\
\text { ke- }\end{array}$} & \multicolumn{3}{c}{ K uat Penerangan (Lux) } \\
titik 1 & titik 2 & Gain \\
\hline 1 & 188,59 & 786,45 & 4,17 \\
2 & 185,86 & 786,45 & 4,23 \\
3 & 196,99 & 808,16 & 4,10 \\
4 & 199,85 & 797,24 & 3,99 \\
5 & $196,99775,81$ & 3,94 \\
6 & $191,36754,94$ & 3,95 \\
7 & $188,59765,31$ & 4,06 \\
8 & $185,86775,81$ & 4,17 \\
9 & $194,16786,45$ & 4,05 \\
10 & $196,99786,45$ & 3,99 \\
\hline \hline \multicolumn{4}{c}{ Average Gain 4,07 }
\end{tabular}

Pengukuran gain dilakukan dengan cara membandingkan nilai kuat penerangan pada titik 2 dan titik 1 pada Gambar 5, secara matematis dapat dituliskan sebagai berikut :

$$
\text { Gain }=\frac{E_{2}}{E_{1}}
$$

dengan $E_{1}$ dan $E_{1}$ menyatakan kuat penerangan titik 1, dan titik 2.

Hasil pengukuran kuat penerangan pada setiap titik terebut, didapat gain sekitar 4 kali dari sumber cahaya asal. Pengukuran efisiensi pada solar illumination dilakukan dengan cara pengukuran kuat penerangan pad titik 1 dan titik 3 . Hasil pengukuran tersebut nantinya akan digunakan untuk perhitungan efisiensi cahaya yang mampu ditransmisikan oleh sistem tersebut. Perhitungan efisiensi mengunakan Pers.2.

$$
\text { \%efisiensi }=\left(1-\frac{I_{i}-I_{t}}{I_{i}}\right) \times 100 \%
$$

dengan $I_{i}, I_{t}$ adalah intensitas cahaya masuk dan intensitas cahaya keluar.

Dari hasil pengukuran didapat data sebagaimana ditunjukkan pada Tabel 2.

\section{SIMPULAN}

Berdasarkan hasil penelitian, diperoleh kesimpulan bahwa

1. Untuk membantu meghadirkan pencahayaan alami pada ruang tertutup dapat mengunakan teknologi solar illumination yang merupakan gabungan dari sistem solar tracker dan sistem instrumentasi optik (solar concentrator dan panel transmisi cahaya).

2. Kemampuan solar tracking dalam mengikuti arah berkas sumber cahaya akan berkontribusi pada optimalisasi jumlah berkas cahaya yang diterima oleh panel solar concentrator.

3. Cahaya yang terfokus mampu ditransmisikan ke dalam ruang gelap mengunakan fiber optik. 
TABEL II: Data Efisiensi Transmisi Cahaya

\begin{tabular}{lcccccccccc}
\hline \hline $\begin{array}{l}\text { Sudut } \\
\text { (derajat) } \\
\text { Lampu }\end{array}$ & \multicolumn{8}{c}{ Kuat penerangan sumber cahaya di titik-1 $=251.5$ lux $)$} \\
& I & Efisiensi & II & Efisiensi & III & Efisiensi & IV & Efisiensi & V & Efisiensi \\
& (lux) & (\%) & (lux) & (\%) & (lux) & (\%) & (lux) & (\%) & (lux) & (\%) \\
\hline & & & & & & & & & & \\
0 & 25,7 & 11,9 & 25,7 & 11,9 & 25,6 & 11,9 & 26,5 & 12,3 & 27,3 & 12,7 \\
10 & 25,4 & 11,8 & 25,5 & 11,8 & 27,6 & 12,8 & 27,5 & 12,8 & 27,1 & 12,6 \\
20 & 23,0 & 10,7 & 25,4 & 11,8 & 25,6 & 11,9 & 25,6 & 11,9 & 25,3 & 11,7 \\
30 & 25,6 & 11,9 & 25,6 & 11,9 & 27,5 & 12,8 & 27,6 & 12,8 & 26,3 & 12,2 \\
40 & 28,3 & 13,1 & 25,7 & 11,9 & 25,0 & 11,6 & 26,7 & 12,4 & 26,4 & 12,3 \\
50 & 27,4 & 12,7 & 27,7 & 12,9 & 24,0 & 11,1 & 27,3 & 12,7 & 27,8 & 12,9 \\
60 & 25,3 & 11,7 & 28,5 & 13,2 & 28,1 & 13,0 & 27,5 & 12,8 & 28,0 & 13,0 \\
70 & 24,6 & 11,4 & 25,6 & 11,9 & 29,2 & 13,5 & 26,5 & 12,3 & 26,0 & 12,1 \\
80 & 25,2 & 11,7 & 26,6 & 12,3 & 27,1 & 12,6 & 25,5 & 11,8 & 27,1 & 12,6 \\
90 & 26,7 & 12,4 & 25,0 & 11,6 & 29,0 & 13,5 & 25,6 & 11,9 & 28,0 & 13,0 \\
100 & 28,9 & 13,4 & 27,3 & 12,7 & 25,3 & 11,7 & 27,0 & 12,5 & 26,8 & 12,4 \\
110 & 26,5 & 12,3 & 28,1 & 13,0 & 26,2 & 12,2 & 28,3 & 13,1 & 27,8 & 12,9 \\
120 & 27,3 & 12,7 & 27,4 & 12,7 & 27,3 & 12,7 & 29,1 & 13,5 & 25,3 & 11,7 \\
130 & 29,5 & 13,7 & 26,5 & 12,3 & 28,4 & 13,2 & 27,3 & 12,7 & 26,7 & 12,4 \\
140 & 22,4 & 10,4 & 27,5 & 12,8 & 27,1 & 12,6 & 26,5 & 12,3 & 26,0 & 12,1 \\
150 & 27,2 & 12,6 & 25,4 & 11,8 & 28,0 & 13,0 & 28,7 & 13,3 & 27,2 & 12,6 \\
160 & 25,2 & 11,7 & 25,6 & 11,9 & 26,0 & 12,1 & 27,1 & 12,6 & 25,3 & 11,7 \\
170 & 24,3 & 11,3 & 26,3 & 12,2 & 26,3 & 12,2 & 27,3 & 12,7 & 27,5 & 12,8 \\
180 & 25,4 & 11,8 & 27,5 & 12,8 & 25,1 & 11,6 & 26,3 & 12,2 & 26,3 & 12,2 \\
Rata-Rata & & 12,1 & & 12,3 & & 12,4 & & 12,6 & & 12,4 \\
\hline \hline
\end{tabular}

Dari hasil perhitungan didapat rata-rata efisiensi adalah sekitar $12 \%$.

4. Panel solar concentrator mampu mengumpulkan dan menguatkan berkas cahaya pada titik fokus hingga 4 kali dari kuat penerangan cahaya asal.

5. Teknologi solar illumination yang telah dirancang memiliki efisiensi sekitar 12,00\% yang terukur dari perbandingan cahaya yang masuk dan keluar dari sistem.
[1] Kementerian Negara Riset dan Teknologi Republik Indonesia, INDONESIA 2005 - 2025 BUKU PUTIH Penelitian Pengembangan dan Penerapan Ilmu Pengetahuan dan Teknologi, (Jakarta, 2006)

[2] Yahya, Harun, Rancangan pada Cahaya dan Desain dalam Warna,(http://www.harunyahya.com/indo/index.php., 1999.)

[3] Phillip, Derek, Lighting Modern Building (Architectural Press, Oxford, 2000)

[4] Ryer, Alex, Light Measurement Handbook (International Light
Inc. 1998)

[5] Halliday, Resnick, Fundamentals of Physics (John Wiley \& Sons, Inc., 1993)

[6] —, Fiber Optik ( http: /www.Wikipedia.com./fiberoptic , 2005)

[7] Eko putro, Agfianto, Belajar Mikrokontroler (Gava Media, Yogyakarta, 2003.)

[8] Budiharto, Widodo, 10 proyek robot Spektakuler (Elex Media Komputindo dan Gramedia, Jakarta, 2008.) 